\title{
学術・技術論文
}

\section{ホビー用小型無人ヘリコプタの自律制御 一機首方向変動を考慮した予見制御による軌道追従制御—}

\author{
羽 沢 健 作*1 辛 振 玉*1 藤 原 大 悟*1 \\ 五十嵐 一 弘*1 Dilshan Fernando*1 野 波 健 蔵*2
}

\section{Autonomous Flight Control of Hobby-Class Small Unmanned Helicopter — Trajectory Following Control by Using Preview Control Considering Heading Direction-}

\author{
Kensaku Hazawa*1, Jinok Shin*1, Daigo Fujiwara*1, \\ Kazuhiro Igarashi*1, Dilshan Fernando*1 and Kenzo Nonami*2
}

\begin{abstract}
In this paper, we design a feed-forward trajectory following controller by using optimal preview control theory for a helicopter, based on its transition model and an LQI position controller derived from previous work. In order to apply optimal preview control theory to trajectory following control at any given yaw angle, we propose a correction method for eliminating disturbances due to attitude perturbations on the magnetic direction sensor. We show the axis transform of position and velocity has a problem and as a result it can not be applied to optimal preview control at any given yaw angle. To solve it, we propose alternative axis transform method. Finally, the performance of the designed preview controller and the proposed axis transform were verified by "circular" and "S character" trajectory following experiments.
\end{abstract}

Key Words: Autonomous Flight Control, Hobby-Class Small Unmanned Helicopter, LQI Control, Preview Control, Trajectory Following Control

\section{1.はじめに}

ヘリコプタは他の固定翼機に比べ，ホバリング，垂直離着陸 などの特殊な飛行が可能であり，空撮，レスキューなどに使用 されてきた。型無人へリコプタは上述の飛行性能に加え，コ ストパフォーマンスや利便性に優れ，危険用途にも使用が可能 であり，将来的に様々な応用が期待されている。

一方，小型無人ヘリコプタの操縦を習得するには，非常に長 い練習期間が必要であり，また遠隔操縦のため飛行範囲が有視 界に限定される。こういった問題を解決するため，近年国内外 で小型無人へリコプタの自律制御に関する研究が行われている.

この種の研究は, 全世界で十数の研究機関で行われており, 様々な研究論文が公表されているが，軌道追従制御に関する報 告は少ない.その中でも，文献 [1] では円軌道を追従させる実 験を行っているが, 速度目標值を円軌道に合わせ作成している ため，任意軌道追従への拡張は困難である。また，文献 [2]で は軌道計画法について述べているが，制御系設計を含めた追従

原稿受付 2005 年 3 月 4 日

${ }^{* 1}$ 千葉大学大学院自然科学研究科

*2 千葉大学工学部

${ }^{* 1}$ Graduate School of Science and Technology, Chiba University

${ }^{* 2}$ Faculty of Engineering, Chiba University
法については述べられていない，軌道計画法のアルゴリズムは， 速度目標值の差分，積分演算を行うことにより，位置，姿勢目 標值を算出しているため，アルゴリズム的には煩雑である．文 献 [3] でもスプライン関数を用いヘリコプタの速度軌道を作成 する方法を提案しているが，追従性能は必ずしも良好ではない． また，フィードフォワード制御を無人ヘリコプタの軌道追従に 適用した例は皆無である。

ヘリコプタはホロノミック系であるため, 車両や固定翼機に 使用されている軌道追従法はそのままでは適用できない。また， ヘリコプタは yaw 角の変動によって, 姿勢変動 (pitch, roll) に対する加速度の向きが変化するという特性を持っている。し たがって，ヘリコプタの軌道追従を実現する上では，yaw 角変 動を考慮しなければならないため，何らかの座標変換が必要と なる。

筆者らは, 先行研究 [4]において, 最適制御理論により 1 型 のサーボ系を構成し，高精度な位置制御に成功している。また， その位置制御系に時間变化する目標值を与え，正方形軌道追従 を行った．しかし，曲線軌道を与えるとフィードバック系のみに よる制御系では，目標值に対する位相遅れが大きく，十分な軌 道追従性を得ることができない。フィードバック系のみによっ て位相遅れを補償するためには制御器のゲインを高くする必要 があり，これは安定性の面から問題がある。 
一方, 軌道追従手法として一般によく知られている予見制御 がある。本研究では, 小型無人へリコプタの軌道追従手法とし て予見制御の適用を試みた。本稿では, 予見制御を小型無人へ リコプタに適用する方法について述べる。具体的には，

1. ヘリコプタの併進運動モデル

2. 予見制御によるフィードフォワード制御

3. 磁気方位の補正方法

4. 座標変換手法

である. 1 は先行研究で行われているため, 本稿ではその概略 を述べる．2では，1の併進運動モデルを用いた予見制御系の構 成, 設計方法について述べる. $3 ， 4$ は，ヘリコプタの yaw 角 を任意に変化させながら軌道追従を行うために必要となるもの である。

最後に, 予見制御を適用した小型無人ヘリコプタの軌道追従 実験結果を示す.

\section{2. 自律制御ヘリコプタと座標系}

\section{1 ヘリコプタ}

本稿で扱う制御対象は Fig. 1 に示すへリコプタで，ホビー用 に一般に市販されている “60 クラス”と呼ばれるものとほぼ同 様の大きさである。制御機器を搭載するために必要なぺイロー ドを実現するために, 40 [cc] のガソリンエンジンと, エンジン 出力を向上させるチューンドマフラを採用している点が従来の 機体と異なる点である。ヘリコプタの詳細な仕様を Table 1 に示す。機体重量は現状で約 $15[\mathrm{~kg}]$ であり, ワンマンオペレー ションが十分に可能である.

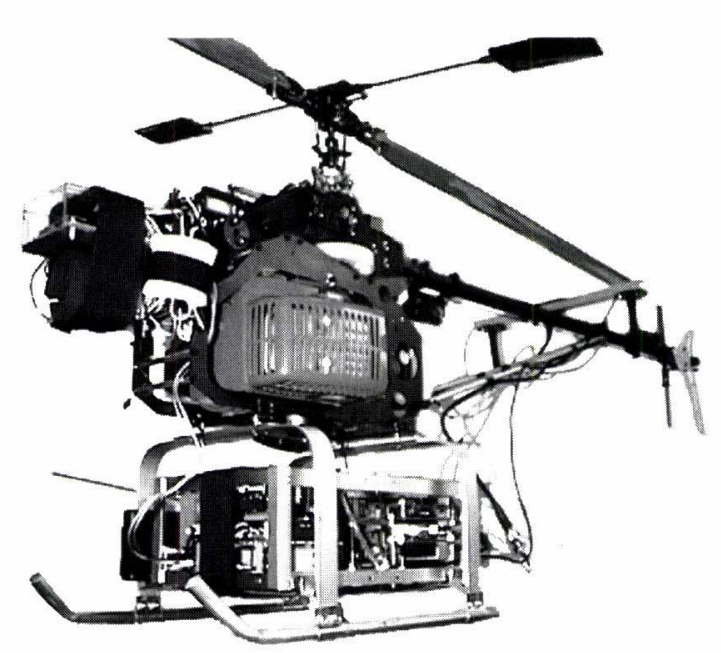

Fig. 1 Overview of helicopter SF40

Table 1 SF40 specification

\begin{tabular}{l|l}
\hline fuselage & HIROBO SF40 \\
\hline main rotor dia. & $1,790[\mathrm{~mm}]$ \\
\hline tail rotor dia. & $273[\mathrm{~mm}]$ \\
\hline length & $1,467[\mathrm{~mm}]$ \\
\hline width & $245[\mathrm{~mm}]$ \\
\hline dry weight & $9,000[\mathrm{gf}]$ \\
\hline full payload capacity & $17,500[\mathrm{gf}]$ \\
\hline engine type & gasoline \\
& 2 stroke, $40[\mathrm{cc}]$ \\
\hline
\end{tabular}

アクチュエータとして, 五つのサーボモータを有し, インナー ループには市販のレートジャイロ, エンジンガバナを安定化装 置として採用している. したがって, 制御対象は上述のアクチュ エータと安定化装置を含めたプラントを考える必要がある.

\section{2 制御システム $[8]$}

制御システムの全体像を Fig. 2 に示す。制御システムは, セ ンサ類，無線モデム，地上局および搭載コンピュータ，ホビー用 ラジコン送信および受信機，パルスジェネレータ, サーボモー 夕により構成される。センサ類の構成は以下のとおりである.

3 軸ジャイロ： pitch, roll 姿勢角速度, 角度を検出. 出力周波 数 $50[\mathrm{~Hz}]$.

RTK-GPS : 機体の緯度, 経度, 高度の位置および速度を検 出. 出力周波数 $10[\mathrm{~Hz}]$.

磁気方位センサ：yaw 角（機首方向）の検出. アナログ出力. ヘリコプタに搭載されたセンサ類によって計測されたデータ は，機体に搭載されたオンボードコンピュータ（Hitachi SH4） に集められ，デー夕転送用のプロトコルに変換される．変換さ れたデータは無線モデムを通して, 地上のコンピュータに送信 され, 制御演算が行われる. 同時に, フライトデー夕の保存, 表 示も実行される、計算された制御指令值（サーボモー夕の回転 角度指令值) は, 本研究グループで独自に開発したパルスジェ ネレータと呼ばれる装置を介して PPM 信号 (Pulse Position Moduration）に変換され，ホビー用ラジコン送信機に送られ る. 最終的に, ホビー用ラジコン受信機によって受信された制 御指令值がサーボモー夕，もしくはインナーループを構成する デバイスに入力される.

\section{3 座標系}

Fig. 3 に座標系を示す.

$\theta, \phi, \psi$ : pitch, roll, yaw 角 $v_{x}^{\prime}, v_{y}^{\prime}, v_{z}^{\prime}$ : 前後, 左右, 上下方向速度 $X^{\prime}, Y^{\prime}, Z^{\prime}$ : 前後, 左右, 上下方向位置

簡単のため, 座標系は pitch, roll 姿勢変動に対して回転しな いものを考える。 つまり, Fig. 3 の $X^{\prime}-Y^{\prime}$ 平面は, 常に水平面 と平行である。しかし, $X^{\prime}-Y^{\prime}-Z^{\prime}$ 系は, yaw 角の変動によっ て回転するものを考える.

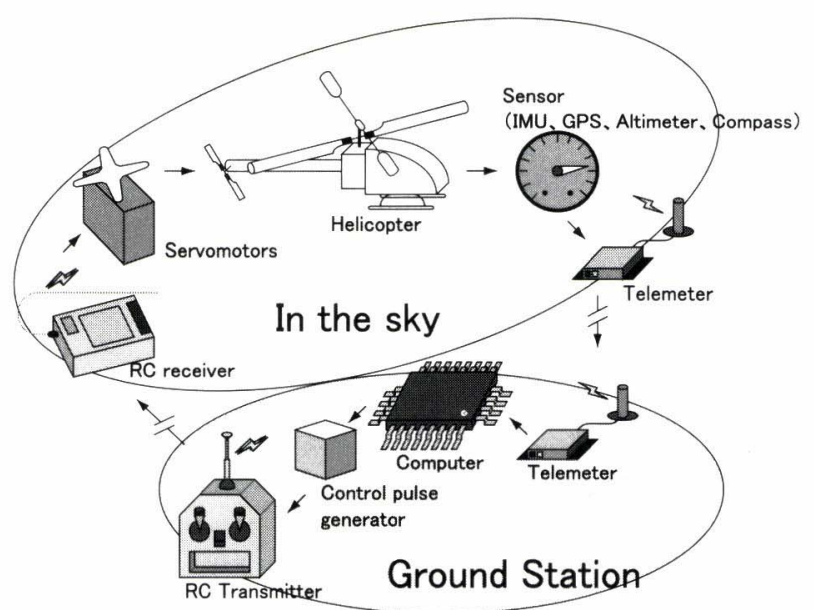

Fig. 2 Overview of host-computer based control system 


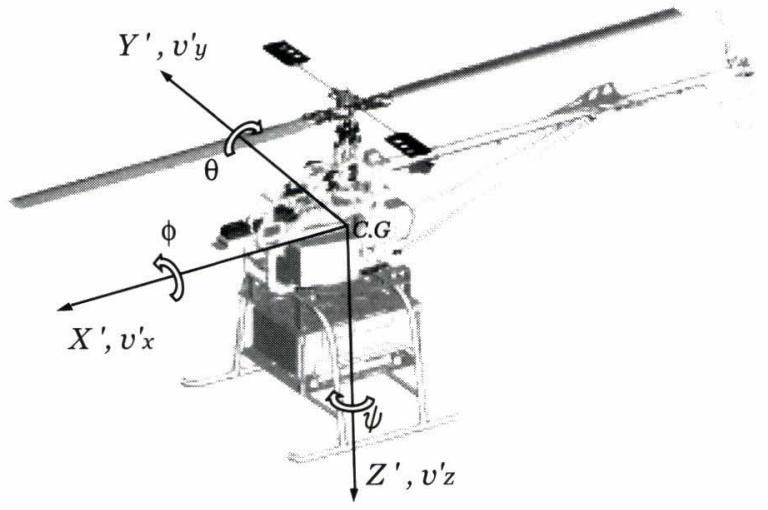

Fig. 3 Local coordinate system

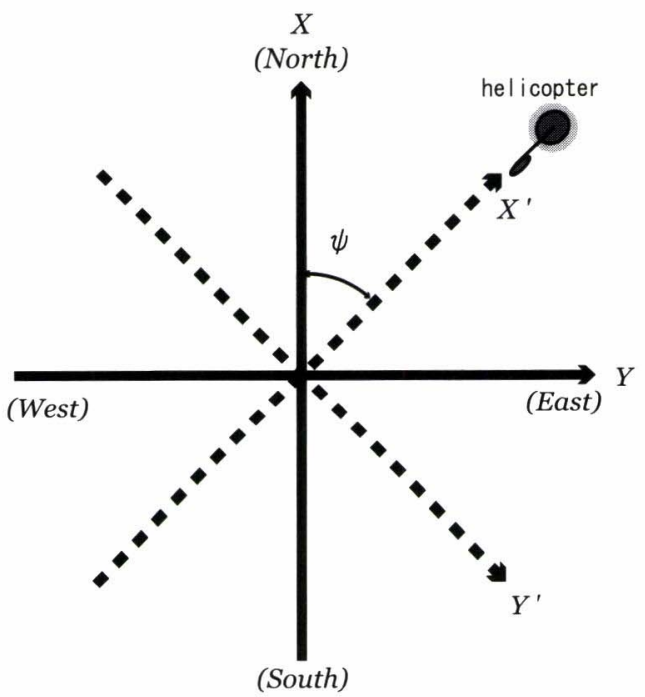

Fig. 4 Global coordinates system

一方, 地球固定座標系として, Fig. 4 に示す $X-Y-Z$ 系を考 える。これは, yaw 角の回転による影響を受けない座標系であ る. Fig. 3 は便宜上，機体重心と座標中心が一致するように描 かれているが， $X^{\prime}-Y^{\prime}-Z^{\prime}$ 系の座標中心は, Fig. 4 に示すよう に $X-Y-Z$ 系の原点と一致する。つまり，yaw 角が 0 度（機首 が北を向いている状態) で，2 種の座標系は完全に一致するこ とになる

\section{3. ヘリコプタ並進運動モデル}

並進運動モデルの導出および並進運動制御は，先行研究 [4] で 行われているため，概略を説明する。ヘリコプタがホバリング に近い状態では $\mathrm{z}$ 軸方向の加速度が小さいため, メインロータ による揚力はへリコプタの自重に等しいと仮定できる（Fig. 5 参照)、したがって, 簡単な力学解析により, 機体前後方向併進 運動に関して以下のモデルが得られる。

$$
\ddot{X}=g \tan (\theta) \cong g \theta
$$

ここで, $g$ は重力加速度である.

式（1）は，機体の姿勢角度に重力加速度を掛けたものが直 接的（静的な関係）に加速度となることを示している。しかし，

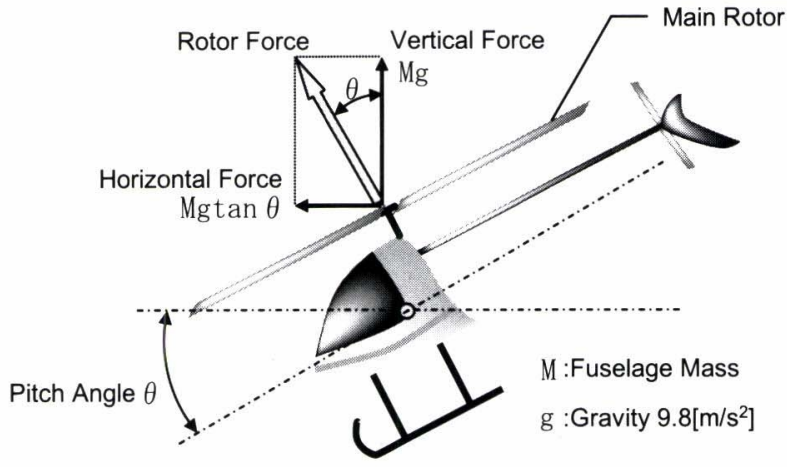

Fig. 5 Pitch attitude and acceleration

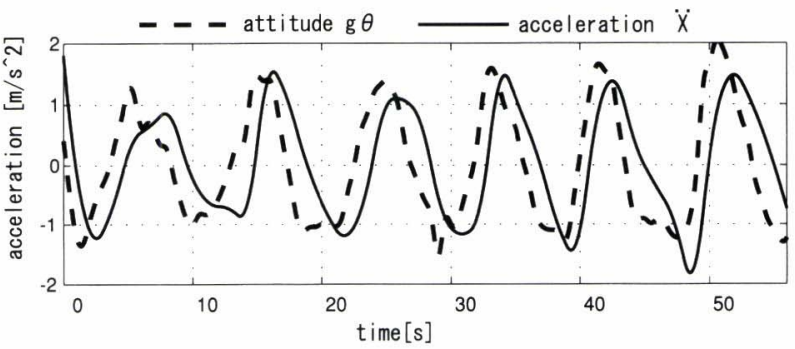

Fig. 6 Phase lag between attitude and acceleration

機体の姿勢変動と実際の加速度の間には位相遅れが存在する。 Fig. 6 は，実験により機体の姿勢を周期的に変動させた場合の 機体加速度データを示している.

この動特性は, 現在のところ空力的要因，センサの無駄時間 によるものと推測されるが，詳細な理論的解析は行っていない， 本研究では, Fig. 6 の特性を以下の 1 次遅れ系で近似して式 (1) に取り入れた。

また，文献 [6] においてシステム同定で得られた 13 次 MIMO モデルを参考にし，不安定極を式（1）に加えた。不安定極の值 に関しては，実験データとシミュレーション結果を比較しなが ら決定した。 以下のモデルを最終的に制御器の設計に使用して いる.

$$
X=g \frac{T}{s+T} \frac{1}{s-a} \frac{1}{s} \theta
$$

ここで， $T=2.0 ， a=0.2$ とした. 式 $(2)$ を状態方程式で表 せば,

$$
\begin{gathered}
{\left[\begin{array}{c}
\ddot{X} \\
\dot{X} \\
X
\end{array}\right]=\left[\begin{array}{ccc}
0 & 1 & 0 \\
0 & a & 1 \\
0 & 0 & -T
\end{array}\right]\left[\begin{array}{c}
\ddot{X} \\
\dot{X} \\
X
\end{array}\right]+\left[\begin{array}{c}
0 \\
0 \\
g T
\end{array}\right] \theta} \\
X=\left[\begin{array}{lll}
0 & 0 & 1
\end{array}\right]\left[\begin{array}{c}
\ddot{X} \\
\dot{X} \\
X
\end{array}\right]+[0] \theta
\end{gathered}
$$

となる．以上，機体前後方向の並進運動モデルを導出したが，左 右方向もまったく同様のモデルを使用している.

Fig. 7 に，上記モデルによる速度応答のシミュレーション結 果と，実験結果を示す。 


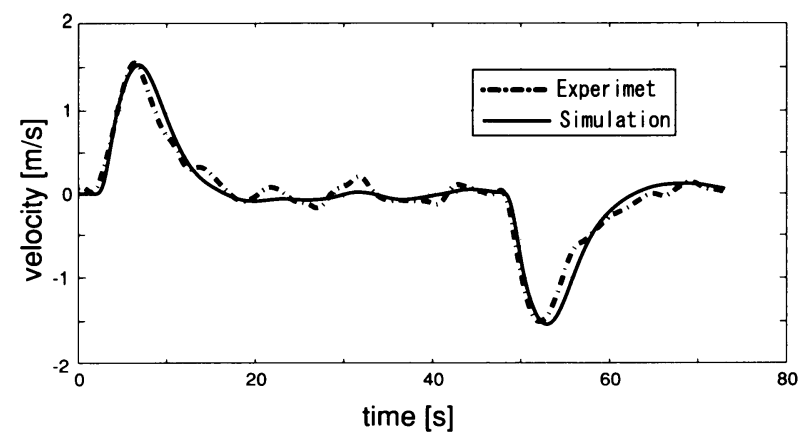

Fig. 7 Simulated and experimental result of velocity response

\section{4. 最適予見制御}

制御対象として，以下のモデルを考える。

$$
\begin{aligned}
x(k+1) & =A_{d} x(k)+B_{d} \theta(k) \\
X(k) & =C_{d} x(k)
\end{aligned}
$$

ここで,

$$
\begin{gathered}
x=\left[\begin{array}{lll}
\ddot{X} & \dot{X} & X
\end{array}\right]^{T} \\
A_{d}=\left[\begin{array}{ccc}
1 & 0.1010 & 0.0047 \\
0 & 1.0202 & 0.0916 \\
0 & 0 & 0.8187
\end{array}\right] \\
B_{d}=\left[\begin{array}{l}
0.0001 \\
0.0016 \\
0.0310
\end{array}\right] \\
C_{d}=\left[\begin{array}{lll}
0 & 0 & 1
\end{array}\right]
\end{gathered}
$$

である，上記の， $A_{d}, B_{d}, C_{d}$ はそれぞれ，式 (3) を離散化 （サンプリング時間 $T_{0}=0.1[\mathrm{~s}]$ ）したものである. 目標軌道を $X_{R}(k)$ として, 愦差信号を次式で定義する.

$$
e(k)=X_{R}(k)-X(k)
$$

ここで, 次のような拡大エラーシステムを導出する.

$$
\begin{aligned}
{\left[\begin{array}{c}
e(k+1) \\
\Delta x(k+1)
\end{array}\right]=} & {\left[\begin{array}{cc}
I & -C A \\
0 & A
\end{array}\right]\left[\begin{array}{c}
e(k) \\
\Delta x(k)
\end{array}\right] } \\
& +\left[\begin{array}{c}
-C B \\
B
\end{array}\right] \Delta \theta(k)+\left[\begin{array}{l}
I \\
0
\end{array}\right] \Delta X_{R}(k+1)
\end{aligned}
$$

ここで, $\Delta x(k)=x(k+1)-x(k), \Delta \theta(k)=\theta(k+1)-\theta(k)$, $\Delta X_{R}(k)=X_{R}(k+1)-X_{R}(k)$ である. 上式を書き直せば,

$$
\begin{aligned}
X_{0}(k+1)= & \Phi X_{0}(k)+G \Delta u(k) \\
& +G_{R} \Delta R(k+1)
\end{aligned}
$$

となる.このエラーシステムに対して, 次式の評価関数を定義 する。

$$
J=\sum_{k=-M_{R}+1}^{\infty}\left[X_{0}^{T}(k) Q X_{0}(k)+\Delta u^{T}(k) H \Delta u(k)\right]
$$

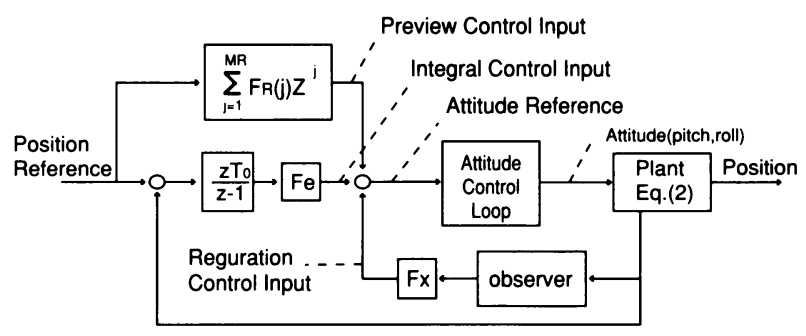

Fig. 8 Block diagram of preview control

ただし, $Q$ : 半正定, $H$ : 正定である (本研究では, $Q$ : 単位行 列, $H: 43$ とした). 上記の評価関数を最小とする制御入力は 以下の式となる $[5]$.

$$
\Delta u(k)=F_{0} X_{0}(k)+\sum_{j=1}^{M_{R}} F_{R}(j) \Delta R(k+j)
$$

ここで,

$$
\begin{aligned}
F_{0}= & {\left[\begin{array}{ll}
F_{e} & F_{x}
\end{array}\right] } \\
= & -\left[H+G^{T} P G\right]^{-1} G^{T} P \Phi \\
F_{R}(j)= & -\left[H+G^{T} P G\right]^{-1} G^{T}\left(\xi^{T}\right)^{j-1} P G_{R} \\
\xi= & \Phi+G F_{0} \\
P= & Q+\Phi^{T} P \Phi \\
& -\Phi^{T} P G\left[H+G^{T} P G\right]^{-1} G^{T} P \Phi
\end{aligned}
$$

である. $M_{R}$, は, 予見ステップ数であり, 何ステップ先の目標 值を制御演算に使用するかを示すパラメータである.

予見フィードフォワードを含めた制御系のブロック線図を Fig. 8 に示す. 予見部分を除くと, Fig. 8 は 1 型のサーボ形 となり,この部分により安定性が保証される.

式（3）の状態量 $\ddot{X}$ はオブザーバにより推定し，残りの状態 量 $\dot{X}, X$ は GPS の出力值を使用している. 式 (3) は, モデ ルへの入力が姿勢角度となっているため, 併進運動制御器の出 力は姿勢角度となる。この姿勢角度を実現するために, 併進運 動制御器のインナーループに先行研究 [7] による姿勢角制御器 を配置している. Fig. 8 中の Attitude Control Loopは, 姿勢 制御閉ループ (姿勢目標值から姿勢角度までのダイナミクス) を示している. 併進運動制御器から見ると, 姿勢制御器は仮想 的なアクチュエータになっている。通常, 制御系設計にはアク チュエータ特性を加味するが, 本研究においては, 姿勢角目標 值から姿勢角の伝達特性を 1 (十分に速い) としている.

\section{5. 磁気方位センサの補正}

本研究では，yaw 角を検出するために磁気方位センサを採用 している.この種のセンサは, 地磁気を二つの磁気センサで検 出し, yaw 角を算出するが, pitch, roll 角の变化により磁気七 ンサも傾き，正確な計測ができない. pitch, roll 角の傾きによ る, 磁気方位センサの変動を Fig. 9 に示す. Fig. 9 は, ヘリコ プタの yaw 角を 130 度（南東向き）に固定し, 機体を地面に水 平に置き, pitch, roll 角を変化させた場合の磁気方位センサの 

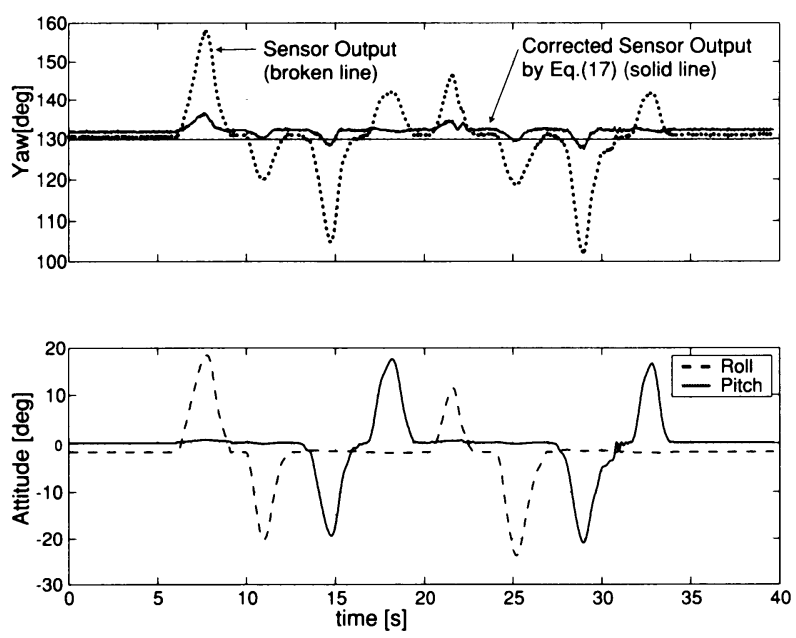

Fig. 9 Corrected and raw yaw data

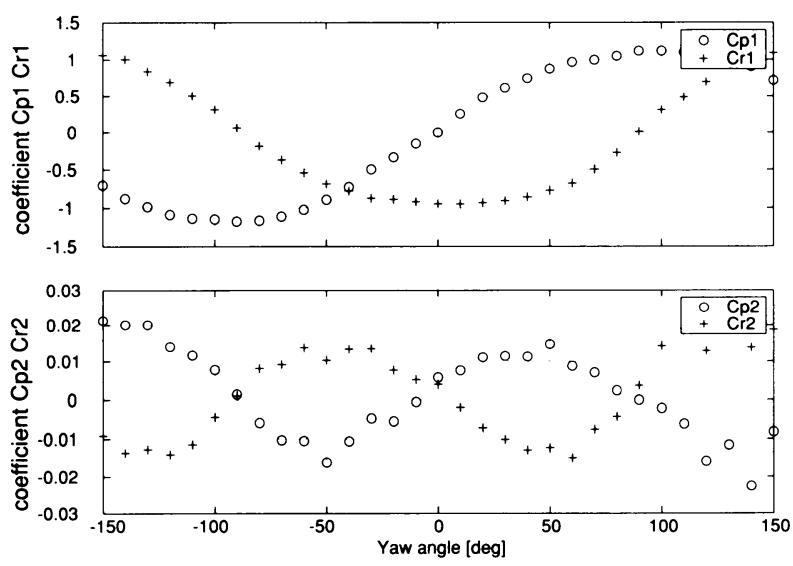

Fig. 10 Coefficients

出力である.上図の破線が磁気センサ出力で下図が姿勢变動で ある．姿勢変動がない場合（0～ $5[\mathrm{~s}])$ は磁気方位センサの出力 は一定であるが，機体姿勢が変動すると（5[s] 以降）磁気方位 センサの出力も大きく変動していることが分かる.

これらの变動を地磁気の伏角などから, 理論的に定式化でき ると思われるが，ここでは実験データより近似的に変動を扱う。

まず, 計測誤差（磁気方位センサ出力 $\psi$ と真值 $\psi_{t}$ との差）を pitch, roll 角の関数として以下の式で近似する.

$$
\psi_{d}=\psi-\psi_{t}=c_{p 1} \theta+c_{p 2} \theta^{2}+c_{r 1} \phi+c_{r 2} \phi^{2}
$$

ここで, $c_{p 1}, c_{p 2}, c_{r 1}, c_{r 2}$ はそれぞれ適当な係数であり, yaw 角の真值 $\psi_{t}$ によって変動するものである. yaw 角の真值 $\psi_{t}$ を $-180 \sim 180$ 度の間を 10 度ずつ变化させ, $c_{p 1}, c_{p 2}, c_{r 1}, c_{r 2}$ を 求めた結果 Fig. 10 のようになった.

これら係数を, 位相, 周期を考慮して, 以下の式で近似した。

$$
\begin{aligned}
& c_{p 1}=A_{p 1} \cos (\psi), \quad c_{p 2}=A_{p 2} \cos (2 \psi) \\
& c_{r 1}=A_{r 1} \sin (\psi), \quad c_{r 2}=A_{r 2} \cos (2 \psi)
\end{aligned}
$$

以上の近似を用いれば,

$$
\psi_{t}=\psi-\psi_{d}
$$

により，七ンサ出力を補正し，yaw 角の真值の近似值を得ること ができる. 式（17）により，最終的に補正をしたyaw 角のデー 夕を Fig. 9 の上図に実線で示す. pitch, roll 角の変動に対して も, yaw 角の真值 (130 度) との䛊差が 5 度程度であり, 上 述の補正が有効に働いていることが分かる.

\section{6. 座 標 変 換}

式（3）は，姿勢角度の変動による機体位置の変化をモデル 化したものである。したがって，座標系としては，機首方向に よって変化する Fig. 4 の $X^{\prime}-Y^{\prime}$ 系に対するものである. 一方, GPS によって計測される位置, 速度情報はFig. 4 の $X-Y$ 系 に従うものである。任意機首方向での併進運動制御を行う場合, 何らかの座標変換を施す必要がある.

\section{1 センサ情報の座標変換}

座標変換の一つの方法として, センサ情報の座標変換（以下， 手法 1) が考えられる。これは， $X^{\prime}-Y^{\prime}$ 系を中心に取り扱うこと と同様で, $X-Y$ 系で表される位置, 速度の計測デー夕を, $X^{\prime}-Y^{\prime}$ 系に変換するものである，具体的には，以下の座標変換を行う．

$$
\begin{gathered}
{\left[\begin{array}{l}
X^{\prime} \\
Y^{\prime}
\end{array}\right]=T\left[\begin{array}{l}
X \\
Y
\end{array}\right],\left[\begin{array}{l}
v_{X^{\prime}} \\
v_{Y^{\prime}}
\end{array}\right]=T\left[\begin{array}{l}
v_{X} \\
v_{Y}
\end{array}\right]} \\
T=\left[\begin{array}{cc}
\cos \psi & \sin \psi \\
-\sin \psi & \cos \psi
\end{array}\right]
\end{gathered}
$$

\section{2 制御入力の座標変換}

前節とは逆に $X-Y$ 系を中心に考えると, $\mathrm{X}, \mathrm{Y}$ 方向のそれ ぞれの位置制御器の出力は, yaw 角が 0 度のときの pitch, roll 角目標値となる。しかし，実際には yaw 角は 0 ではないため， その值を直接 pitch, roll 角目標値として与えることはできな い.そこで，以下のような座標変換を考える。

$$
\left[\begin{array}{l}
P_{r} \\
R_{r}
\end{array}\right]=T\left[\begin{array}{l}
u_{x} \\
u_{y}
\end{array}\right]
$$

ここで， $P_{r}, R_{r}$ はそれぞれ pitch 角, roll 角目標值, $u_{x}, u_{y}$ はそれぞれ X, Y 方向の位置制御器の出力である.この手法は, $X-Y$ 系を中心に考え, 位置プラントへの制御入力（姿勢角目 標値）を座標変換（以下，手法 2）していることになる.

\section{3 座標変換手法の選択}

簡単のため Fig. 8 に示す図の予見フィードフォワード項を除 いた部分で考える。予見部分を除けば, Fig. 8 は式（3）に対す る 1 型のサーボ系となる. 以上の状態で前節の手法 1 を使用し て制御を行った場合のシミュレーション結果を Fig.11〜13に 示す.

シミュレーションはまず, 原点 $(0,0)$ から始まり， $(0,10)$ まで移動する。 その状態で yaw 角を 90 度から 0 度へ変化させ ている。このときセンサ情報の座標変換は手法 1 によって行わ れているため, $(0,10)$ にいる状態で yaw 角の変化と同時に, $X^{\prime}$ 座標は $10[\mathrm{~m}]$ から $0[\mathrm{~m}]$ へと変化する. 同様に, $Y^{\prime}$ 座標も $0[\mathrm{~m}]$ から $10[\mathrm{~m}]$ へと変化する.この場合, 状態フィードバッ クによるレギュレーション入力が急激に変化し, 積分による制 


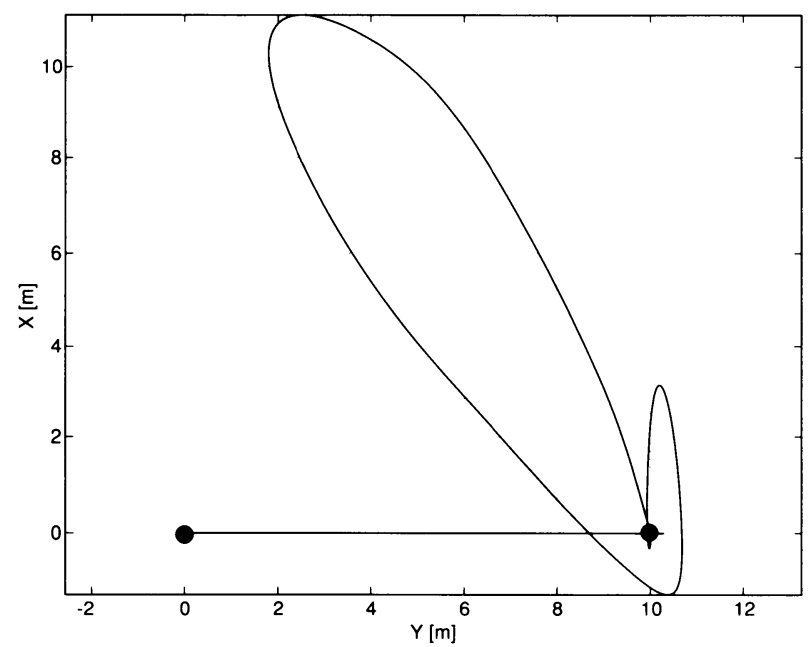

Fig. 11 Simulated position control result with method $1(X-Y$ plot)
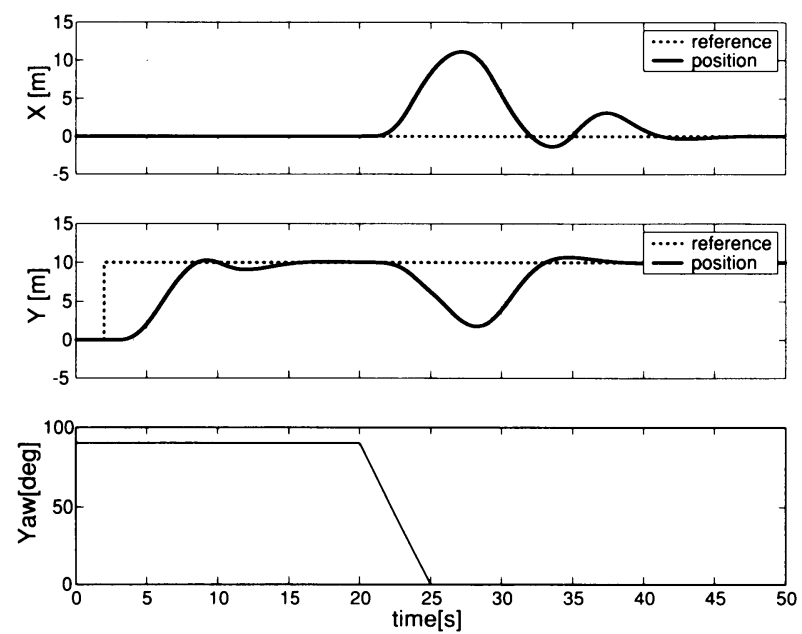

Fig. 12 Simulated position control result with method 1 (time domain plot) and yaw angle

御入力との釣り合いが崩れる.このため, 最終的な制御入力も 大きく乱れ, 最終的に機体の位置が目標位置と大きくずれてし まう。これは, レギュレーション入力は静的な写像であるのに 対し, 積分には動特性があるため, yaw 角の変化に伴い崩れた 両者の釣り合い関係がもう一度釣り合い状態に戻るまでに時間 を有するからである．以上の様子を Fig. 13 に示す，yaw 角の 変化が始まる $20[\mathrm{~s}]$ 付近から, 釣り合い状態が崩れ, 制御入力 が飽和していることが分かる. また，積分入力が 23 秒付近から 27 秒付近まで変化しないのは, アンチワインドアップフィル夕 を使用しているためである.

以上は，予見制御を含まない形でのシミュレーションである が，予見制御を含む場合は，上述の 2 種の制御入力に加え予見 入力との釣り合いが生じてくる.したがって問題はより複雑に なるため, 手法 1 を用いると状況がさらに悪化することは容易 に予想ができる，よって，本研究で目標とする任意機種方向の 軌道追従には, 手法 2 が有効である。

手法 1, 手法 2 の概略を Fig. 14 に示す. 図中の $X r, Y r$ はそ

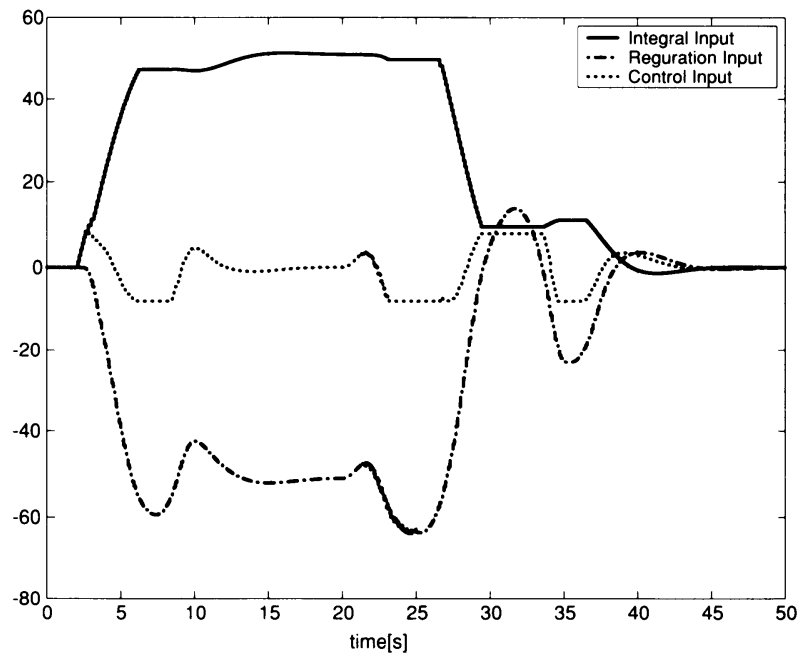

Fig. 13 The disturbance on control input trim condition due to axis transform (method 1 )

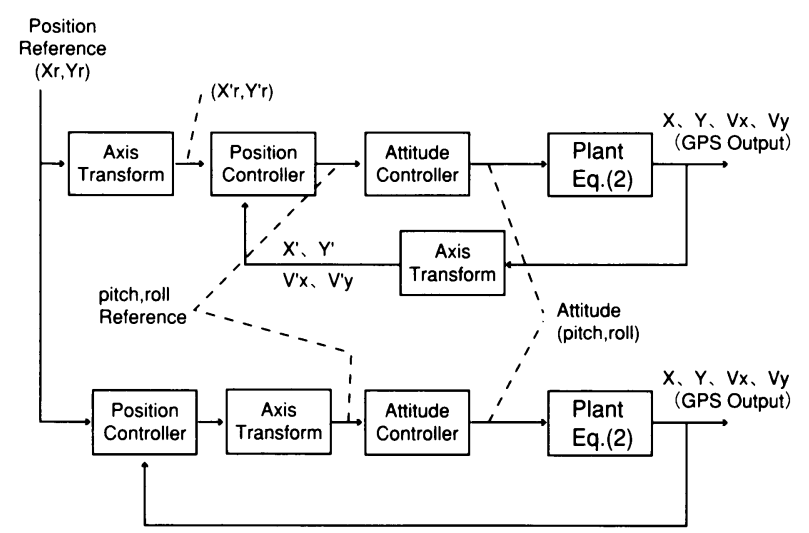

Fig. 14 Two kind of axis transform (upper: method 1, lower: method 2)

れぞれ $X-Y$ 系における目標位置, $X^{\prime} r, Y^{\prime} r$ はそれぞれ $X^{\prime}-Y^{\prime}$ 系における目標位置である。後の実験においては，すべて手 法 2 を用いている.

\section{7. 実験}

予見ゲイン $F_{R}$ は，式（14）よりフィードバック系を含めた 形で設計されるため, フィードバック系は先行研究 [4] で求め た実績のある 1 型のサーボ系をそのまま用い，その設計重みに 基ついいて予見ゲイン $F_{R}$ を求めた。 また，予見数はシミュレー ションにより調整をし，最終的には $M_{R}=60$ とした。制御系 のサンプリング時間が $0.1[\mathrm{~s}]$ であるため，この予見数は，6 秒 先までの目標值情報を制御演算に反映していることになる。

予見ステップ数は $M_{R}=60$ としているが, $M_{R}=30$ 程度 でもほほ同等の制御性能が得られることをシミュレーションで 確認している. 参考に予見ステップ数と式 (9) の評価関数の值 をFig.15に示す．実機においては，むだ時間，七ンサノイズ， 姿勢制御系の特性等, 4 章の設計では考慮していない要素が含 まれるため，それらを考慮したシミュレーションにより予見ス テップ数を決定する必要がある. 


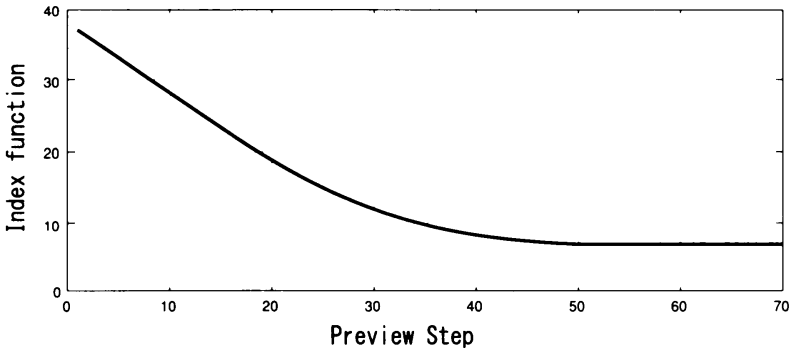

Fig. 15 Index function and preview step

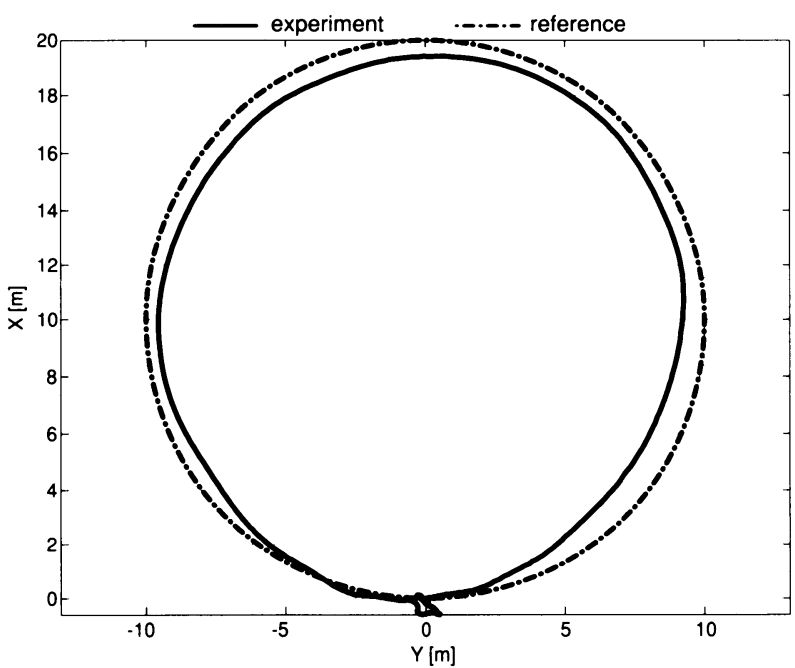

Fig. 16 Experimental result of preview control $(X-Y$ plot, circular trajectory)
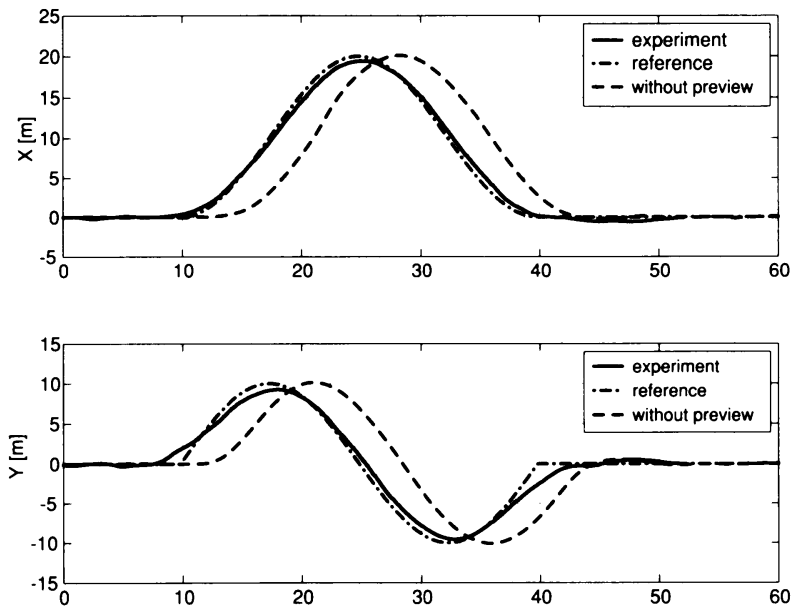

Fig. 17 Experimental result of preview control $(X-Y$ time domain response)

\section{実験結果を Fig. 16〜19 に示す.}

Fig. 16 と Fig. 17 は, 半径 $10[\mathrm{~m}]$ の円を 30 [s] で 1 周する目 標軌道を与えた場合の奏験結果である。この実験は，yaw 角を 北に向けて固定した状態で行った．Fig. 17 において，予見制御 を付加しない場合のシミュレーション結果と比較すると，位相 特性が大きく改善され，高精度な軌道追従が予見制御によって 実現されていることが分かる。この場合の比較は，まったく同
五十嵐一弘 Dilshan Fernando 野波健蔵

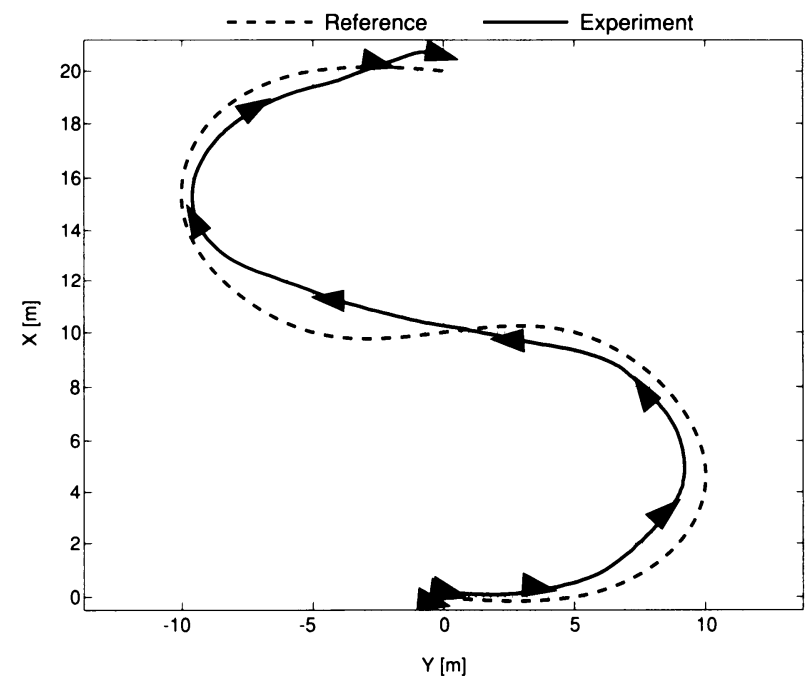

Fig. 18 Experimental result of preview control $(X-Y$ plot, $\mathrm{S}$ trajectory)
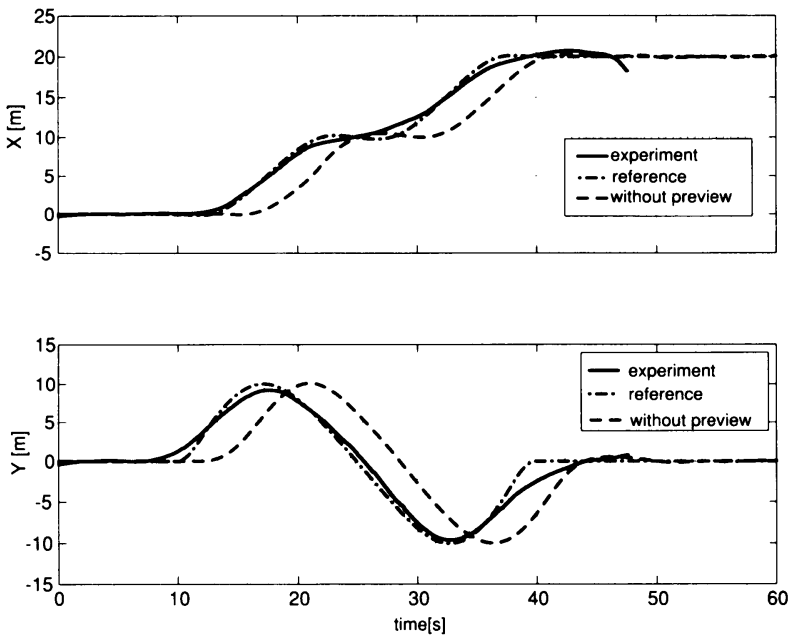

Fig. 19 Experimental result of preview control $(X-Y$ time domain response, $\mathrm{S}$ trajectory)

様のフィードバック系を用いて行った. したがって，Fig. 17 の 2 者の違いは予見フィードフォワードの有無のみである.

Fig. 18 と Fig. 19 は, S 字軌道を与えた場合の実験結果であ る。この実験においては，yaw の座標変換を取り人れ，機首方 向が常に進行方向を向くように yaw 角の制御を行った. Fig. 18 において，二等辺三角形の鋭角が yaw 角の向きを示している. 任意座標において yaw 角の変動が起こっても，本稿で提案した 座標変換手法が有効に働いていることが分かる.

\section{8.おわりに}

本稿では, 先行研究 [4] で得られた並進運動モデルと最適制 御理論による位置制御系を基にし，最適予見制御によるフィー ドフォワード制御系を構成した。また，姿勢角変動に対する方 位角補正法を提案した。さらに，従来の位置，速度情報の座標 変換の問題点を明確に示し，制御入力の座標変換を取り入れた 制御系の構築を行った。 
子見制御を適用した場合に，目標値に対する追従特性が大幅 に改善されることを，予見制御を含まない最適制御系による実 験結果と比較することで検証した。 また，制御入力の座標変換 により，任意 yaw 角で軌道追従制御が可能であることを $\mathrm{S}$ 字軌 道追従制御実験により検証した。

本研究で提案した手法は, 他の手法 [2]に比べ, アルゴリズ 么的にも分かりやすく, 予見ステップ数を調整することで, 才 ンラインの計算量も比較的少なくて济む. また，制御系に与え るべき目標值は, 時系列の二次元地球固定座標, およびyaw 角 データの 3 種類であり, 外部的にも内部的にも速度目標值を利 用しないため, ユーザ側から見れば非常に簡略化されたシステ ムとなる。以上から，本手法はへリコプタの軌道追従制御法と して非常に有効な手段であると考えられる。

今後は, フィードバック系の性能を高め, より高速な軌道追 従を行っていく，また，本研究ではへリコプタの $\mathrm{x}-\mathrm{y}$ 平面での 軌道追従について述べたが, 今後は本手法を高度制御に拡張し, 三次元空間での軌道追従を行って行きたい.

謝 辞 本研究を行うに当たり，様々なご協力をいただいた ヒロボー (株) の皆様, および双葉電子工業（株）の皆様に心 から感謝いたします。

\section{参 考 文 献}

[1] M. La Civita, G. Papageorgiou, W.C. Messner and T. Kanade:
"Design and Flight Testing of a High-Bandwidth $\mathrm{H} \propto$ Loop Shaping Controller for a Robotic Helicopter," Proceedings of the AIAA Guidance, Navigation, and Control Conference, 2002.

[2] ヤマ八発動機（株): 無人ヘリコプタの飛行制御システム, 特開 2000118498,2000

[3] K. Harbick, J.F. Montgomery and G.S. Sukhatme: "Planar Spline Trajectory Following for an Autonomous Helicopter," 2001 IEEE International Symposium on Computational Intelligence in Robotics and Automation, 2001.

[4] K. Hazawa, J. Shin, D. Fujiwara, K. Igarashi, D. Fernando and K. Nonami: "Autonomous Flight Control of Unmanned Small Hobby-Class Helicopter, Report 2: Modeling Based on Experimental Identification and Autonomous Flight Control Experiments," Journal of Robotics and Mechatronics, vol.15, no.5, pp.546-554, 2003.

[5] 土浴武士，江上正：ディジタル子見制御。産業図書, 1992.

[6] B. Mettler, M. Tischler and T. Kanade: "System Identification Modeling of a Small-Scale Unmanned Rotorcraft for Flight Control Design," American Helicopter Society Journal, vol.47, no.1, pp.50-63, 2002.

[7] 辛振玉, 藤原大悟, 羽沢健作, 野波健蔵：“ラジコンヘリコプタの姿 勢・ホバリング制御”, 日本機械学会論文集 ( C 編), vol.68, no.675, pp. $148-155,2002$.

[8] D. Fujiwara, J. Shin, K. Hazawa, K. Igarashi, F. Dilishan and K. Nonami: "Autonomous Flight Control of Small Hobby-Class Unmanned Helicopter (Report 1: Hardware Development and Verification Experiment of autonomous Flight Control System.)," Jounal of Robotics and Mechatronics, vol.15, no.3, pp. 537-545, 2003.

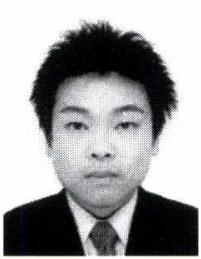

羽沢健作（Kensaku Hazawa）

1979 年 8 月 21 日生. 2002 年 3 月千葉大学工学 部卒業. 2004 年 3 月同大学大学院自然科学研究科 機械システム博士前期課程修了。2004 年 4 月川崎 重工業 (株) 人社. 2005 年 4 月千葉大学大学院自 然科学研究科人士システム科学専攻博士後期課程入 学、現在に至る。小型無人ヘリコプタの自律制御に 関する研究に従事.

(日本ロボット学会正会員)

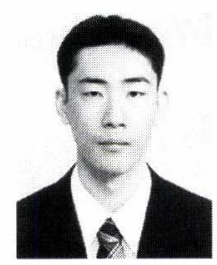

藤原大悟（Daigo Fujiwara）

1978 年 1 月 4 日生. 2000 年 3 月千葉大学工学部 卒業. 2002 年 3 月同大学大学院自然科学研究科機 械システム博士前期課程修了. 2005 年 3 月同大学 院自然科学研究科人工システム科学専攻博士後期課 程修了, 博士 (工学)。2005 年 4 月三菱重工業（株） 入社. 現在に至る。在学中は小型無人へリコプタの 自律制御に関する研究に従事.

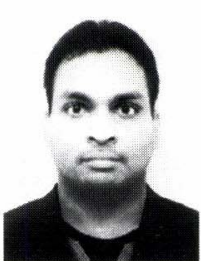

\section{Dilshan Fernando}

1976 年 6 月 22 日生. 2003 年 3 月下葉大学工学部 卒業. 2005 年 3 月同大学大学院自然科学研究科機 械システム博士前期課程修了. 2005 年 4 月トヨ夕 自動車（株）入社．現在に至る。在学中は小型無人 ヘリコプタの自律制御に関する研究に従事.

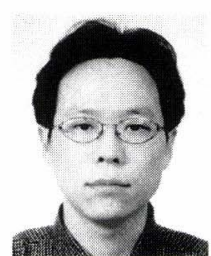

\section{辛 振玉 (Jinok Shin)}

1972 年 1 月 19 日生. 1997 年 8 月 Kookmin 大学 (韓国) 工学部卒業. 2002 年 3 月同大学大学院自然 科学研究科機械システム博士前期課程修了. 2005 年 3 月同大学大学院自然科学研究科人工システム 科学専攻博士後期課程修了, 博士 (工学)。2005 年 4 月双葉電子工業 (株) 入社. 現在に至る。在学中 は小型無人ヘリコプタの自律制御に関する研究に従事.

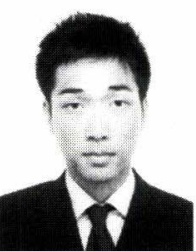

五十嵐一弘（Kazuhiro Igarashi）

1981 年 3 月 31 日生. 2003 年 3 月千葉大学工学部 卒業. 2005 年 3 月同大学大学院自然科学研究科機 械システム博士前期課程修了。2005 年 4 月日産自 動車. (株) 人社. 現在に至る。在学中は小型無人へ リコプタの自律制御に関する研究に従事.

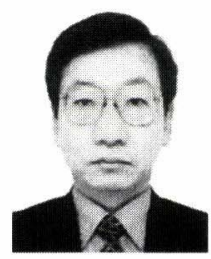

野波健蔵（Kenzo Nonami）

1949 年 2 月 21 日生. 1979 年 3 月東京都立大学 大学院博士課程修了. 工学博士. 千葉大学工学部助 手, 同助教授を経て 1994 年同教授. 現在に至る. この間, 1985 年から 1986 年, 1988 年に米航空宇 宙局 (NASA) 研究員. 小型無人ヘリコプタの自律 制御, UAV ・ MAV の自律制御, 地雷探知ロボット の運動制御, マニピュレータ・ハンドの制御, 磁気軸受フライホイー ルの制御, 制御応用などの研究に従事. 日本機械学会, 計測自動制 御学会, システム制御情報学会, 日本フルードパワーシステム学会, IEEE, ASME, AHS なとの会員. （日本ロボット学会正会員） 